Beata WALAS ${ }^{1}$, Robert DROBINA ${ }^{2}$

Opiekun naukowy: Robert DROBINA ${ }^{2}$

DOI: https://doi.org/10.53052/9788366249844.24

\title{
ZATRUDNIENIE OSÓB NIEPEŁNOSPRAWNYCH W PRZEDSIĘBIORSTWACH PRODUKCYJNYCH
}

Streszczenie: $\mathrm{W}$ artykule przedstawiono definicję osób z niepełnosprawnościami, sposoby przygotowania do pracy $\mathrm{w}$ przedsiębiorstwie produkcyjnym, warunki pracy oraz wybrane sposoby dostosowania przestrzeni pracy dla osoby niepełnosprawnej.

Słowa kluczowe: niepełnosprawność, zatrudnienie, warunki pracy, dostosowanie miejsca pracy

\section{EMPLOYMENT OF DISABLED PEOPLE IN MANUFACTURING COMPANIES}

Summary: This article shows the definition of disabled people, ways of preparing this kind of people to work, the terms of employment and selected ways of workplace adjustments for people with disability.

Keywords: disability, employment, terms of employment, workplace adjustments

\section{Zatrudnienie osób niepełnosprawnych w przedsiębiorstwach produkcyjnych}

Według definicji zawartej w Encyklopedii PWN niepełnosprawność to utrudnienie swobodnego wykonywania codziennych czynności i obowiązków w sposób naturalny lub w zakresie uważanym za normlany dla pełnosprawnego człowieka. Niepełnosprawność jest spowodowana przez różne czynniki i objawia się wadami funkcji organizmu oraz uszkodzeniami[11]. Celem artkułu jest przedawnienie

\footnotetext{
1 Akademia Techniczno- Humanistyczna w Bielsku- Białej, Wydział Budowy Maszyn i Informatyki, specjalność: Inżynieria Zarządzania Produkcją, email: beata.walas01@gmail.com

${ }^{2}$ dr hab. inż., prof. ATH Akademia Techniczno- Humanistyczna w Bielsku- Białej, Wydział Budowy Maszyn i Informatyki, email: rdrobina@ath.bielsko.pl
} 
problematyki zatrudniania osób $\mathrm{z}$ niepełnosprawnością $\mathrm{W}$ przedsiębiorstwach produkcyjnych oraz możliwości adaptacji przestrzeni pracy do wymogów osób Z niepełnosprawnością. Na podstawie Ustawy z dnia 27 sierpnia 1997r. „O rehabilitacji zawodowej i społecznej oraz zatrudnianiu osób niepełnosprawnych” możemy zbudować definicję niepełnosprawności. Niepełnosprawność jest to trwała lub okresowa niemoc do wykonywania czynności. Powodem takiego stanu jest stałe lub długotrwałe uszkodzenie bądź naruszenie sprawności organizmu co powoduje niezdolność do pracy[16]. Osoby niepełnosprawne bardzo cenią sobie możliwość pracy. Daje im to ogromne możliwości począwszy od lepszego samopoczucia spowodowanego wyjściem $\mathrm{z}$ domu co podnosi też ich samoocenę, jednocześnie to daje im możliwość poznania nowych ludzi czy integracji i daje szansę normalnego funkcjonowania w społeczeństwie [18]. Osobom niepełnosprawnym zależy na możliwości samodzielnego utrzymywania się nawet jeśli byłoby to częściowe. Możliwość pracy daje im poczucie użyteczności w społeczeństwie oraz uświadamia im i utwierdza, że takie osoby są potrzebne i wartościowe. Praca daje im również szansę na wykorzystanie wszystkich umiejętności i wiedzy, którą posiedli w czasie nauki oraz pokazuje, że mogą być tak dobrze wykształceni jak pełnosprawni ludzie $[2]$.

\subsection{Przystosowanie osób niepełnosprawnych do pracy w przedsiębiorstwach produkcyjnych}

Niezależnie od tego czy osoba jest niepełnosprawna fizycznie, psychicznie lub umysłowo bądź istnieje zagrożenie, że takie upośledzenie może u niej wystąpić ma ona prawo do pomocy po to by[2]:

- mogła się ona odnaleźć w społeczeństwie, zwłaszcza w pracy, która będzie pasowała do jej umiejętności i wiedzy,

- zapobiegać lub łagodzić skutki upośledzenia tak by się ono nie pogłębiało.

Pomoc osobom z upośledzeniami i osobom zagrożonym upośledzeniem związana $\mathrm{z}$ przystosowaniem do życia zawodowego i społecznego zawiera świadczenia, rehabilitacje i wszystkie niezbędne procesy do kształtowania ich warunków życia. Najważniejsze są świadczenia socjalne, które zawierają rehabilitacje jednak by osoby niepełnosprawne mogły sprawnie wkroczyć w życie społeczne świadczenia muszą być poszerzone o [2]:

- przystosowanie środowiska do potrzeb osób niepełnosprawnych, z którymi zmagają się w życiu codziennym,

- przygotowanie osób niepełnosprawnych i społeczeństwa do wzajemnej integracji.

Osoby z upośledzeniami mimo różnych trudności chcą mieć możliwość podjęcia pracy jeśli tylko jest to możliwe na podstawie tych samych kryteriów oraz w tych samych szkołach, w których uczą się i pracują osoby pełnosprawne. W zasadzie nie ma drogi zawodowej, której nie mogłaby wybrać osoba niepełnosprawna, ale by to wszystko mogło się udać i działać sprawnie konieczna jest już wcześniej wspomniana integracja [2]. Osoby niepełnosprawne przed podjęciem pracy lub zanim dokonają wyboru swojej ścieżki zawodowej muszą się odpowiednio wcześnie przygotować. Musi tutaj zadziałać silna współpraca pomiędzy osobą niepełnosprawną, jej rodzicami czy opiekunami, a szkołą i poradniami zawodowymi. Cała integracja i przystosowanie 
zaczyna się na końcu szkoły ogólnej lub zawodowej ( w zależności od tego jakie są potrzeby i niepełnosprawność danej osoby) gdzie na zajęciach specjalnie do tego przeznaczonych osoby te uczą się życia zawodowego [2].

Aby zaspokoić potrzeby ludzi niepełnosprawnych związane z zatrudnieniem oraz pracą należy realizować działania takie jak [1]:

1) tworzenie coraz większej liczby stanowisk pracy oraz miejsc pracy, które będą również dostępne dla osób niepełnosprawnych,

2) pomoc osobom niepełnosprawnym w załatwieniu spraw związanych z zatrudnieniem, ułatwienie dostępu do informacji o ofertach pracy oraz pomoc w rozwijaniu własnej działalności gospodarczej, która pozwoli stworzyć miejsce pracy im oraz ich rodzinom,

3) poprawianie warunków pracy, dostosowywanie miejsca pracy oraz poprawa warunków płacowych w zakładach zatrudniających niepełnosprawnych, zapobieganie degradacji osób z niepełnosprawnością,

4) pomoc w edukacji, zdobywaniu kwalifikacji lub przekwalifikowywaniu się, podnoszeniu sprawności zarówno fizycznej jak i umysłowej, pomoc w doskonaleniu zawodowym.

Usprawnienia dla osób niepełnosprawnych w przedsiębiorstwach mogą być wykonywane w różny sposób jednak najczęściej polega to na dostosowaniu pomieszczenia oraz sprzętu na stanowisku do potrzeb osoby z niepełnosprawnością. Jest to np. likwidacja barier architektonicznych, budowa podjazdów i wind dla osób z ograniczoną możliwością ruchu. Oprócz tego jako udogodnienie dla osoby niepełnosprawnej możemy zaliczyć dostosowanie czasu pracy do możliwości danej osoby, podział zadań, a nawet udogodnieniem jest przeniesienie stanowiska pracy z wyższego piętra na parter [6-10].

\subsection{Warunki pracy osób niepełnosprawnych}

Osobom niepełnosprawnym w zależności od tego jaki posiada ona stopień niepełnosprawności przysługują w pracy przywileje pracownicze. Dla każdego stopnia te wymagania się w pewnych aspektach różnią i wygląda to następująco [19]:

- Dla osoby z lekkim stopniem niepełnosprawności jest to[19]:

- tygodniowy czas pracy nie przekraczający 40 godzin/ tydzień i tym samym 8 godzin/dzień,

- zakaz pracy w godzinach nadliczbowych, które narzucił pracodawca (chyba, że lekarz wyraził na to zgodę),

- zakaz pracy w godzinach nocnych ( chyba, że lekarz wyraził na to zgodę),

- dodatkowe 15 minut przerwy, które nie obniżają wynagrodzenia,

- możliwość odmówienia udziału w wyjazdach służbowych jeśli stan zdrowia, rodzaj wady utrudnia poruszanie się lub funkcjonowanie w terenie.

- Dla osoby z umiarkowanym lub znacznym stopniem niepełnosprawności warunki pracy przedstawiają się następująco[19]:

- dzienny czas pracy wynosi maksymalnie 7godzin, a tygodniowy nie więcej niż 35 godzin,

- dodatkowe wynagrodzenie za pracę w godzinach nadliczbowych ( najpierw jednak lekarz musi wyrazić zgodę na pracę w godzinach nadliczbowych), 
- dodatkowe 10 dni urlopu, pracownik ma 21 dni w roku do wykorzystania na różnego rodzaju wyjazdy rehabilitacyjne, badania, wizyty lekarskie, zabiegi,

- bez zgody lekarza pracownik nie może pracować w godzinach nocnych,

- dodatkowe 15 minut przerwy bez obniżania wynagrodzenia,

- nie musi zgadzać się na wyjazdy służbowe jeśli niepełnosprawność utrudnia tej osobie funkcjonowanie.

\subsection{Korzyści dla pracodawcy z tytułu zatrudniania osób niepełnosprawnych}

Korzyściami które może zyskać pracodawca zatrudniając osobę niepełnosprawną są[12-15-18]:

- $\quad$ zwolnienie z obowiązkowych wpłat na rzecz Państwowego Funduszu Osób Niepełnosprawnych,

- zwrot kosztów poniesionych na wyposażenie stanowiska pracy z PFRON, jeśli zatrudniona osoba niepełnosprawna jest zarejestrowana jako osoba bezrobotna,

- $\quad$ pokrycie kosztów szkolenia osoby niepełnosprawnej w wysokości nawet $80 \%$ kosztów,

- $\quad$ pracodawca może ubiegać się o dofinansowanie z PFRON do wynagrodzenia dla osoby niepełnosprawnej,

- $\quad$ poprzez zatrudnianie osób niepełnosprawnych firma staje się bardziej konkurencyjna i przyciąga większą ilość potencjalnych klientów,

- $\quad$ wzbogaca się filozofia firmy, jej wizerunek się wzmacnia oraz zyskuje ona na znaczeniu w oczach społeczeństwa,

- $\quad$ zwrot kosztów zatrudnienia ewentualnego pracownika pomagającego pracownikowi niepełnosprawnemu w wykonywaniu niektórych czynności.

\subsection{Aktywność ekonomiczna osób niepełnosprawnych w latach 2018, 2019 i 2020 r}

Według danych GUS w 2018 roku zdecydowana większość osób niepełnosprawnych ( 78,1\% ) pracowała w prywatnym sektorze gospodarki. Pod koniec roku 2018 w podmiotach zatrudniających 10 i więcej osób pracowało 344,9 tys. osób z niepełnosprawnością, a procent zatrudnienia osób niepełnosprawnych w poszczególnych sektorach działalności wygląda następująco [13]:

- usług administrowania i działalności wspierającej $(33,1 \%)$,

$>$ działalność detektywistyczna i ochroniarska (20,2\%),

$>$ działalność usługowa związana $\mathrm{z}$ utrzymaniem porządku w budynkach i zagospodarowaniem terenów zieleni (9,5\%),

- $\quad$ przetwórstwo przemysłowe $(24,6 \%)$,

- $\quad$ opieka zdrowotna $(8,0 \%)$. 


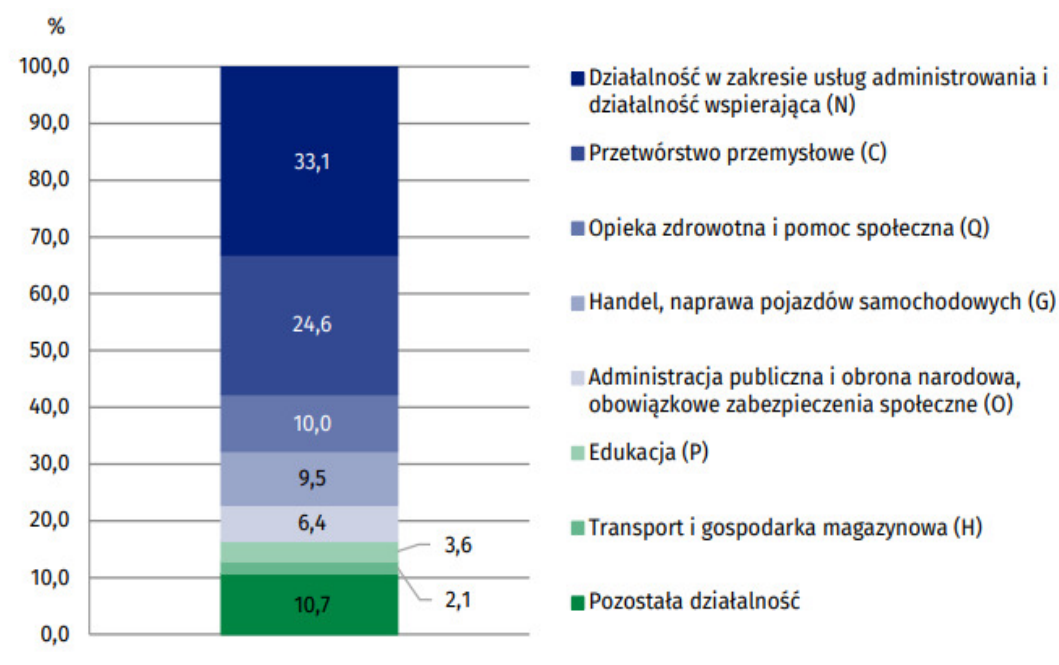

Rysunek 1. Struktura pracujących osób niepetnosprawnych w 2018r [13]

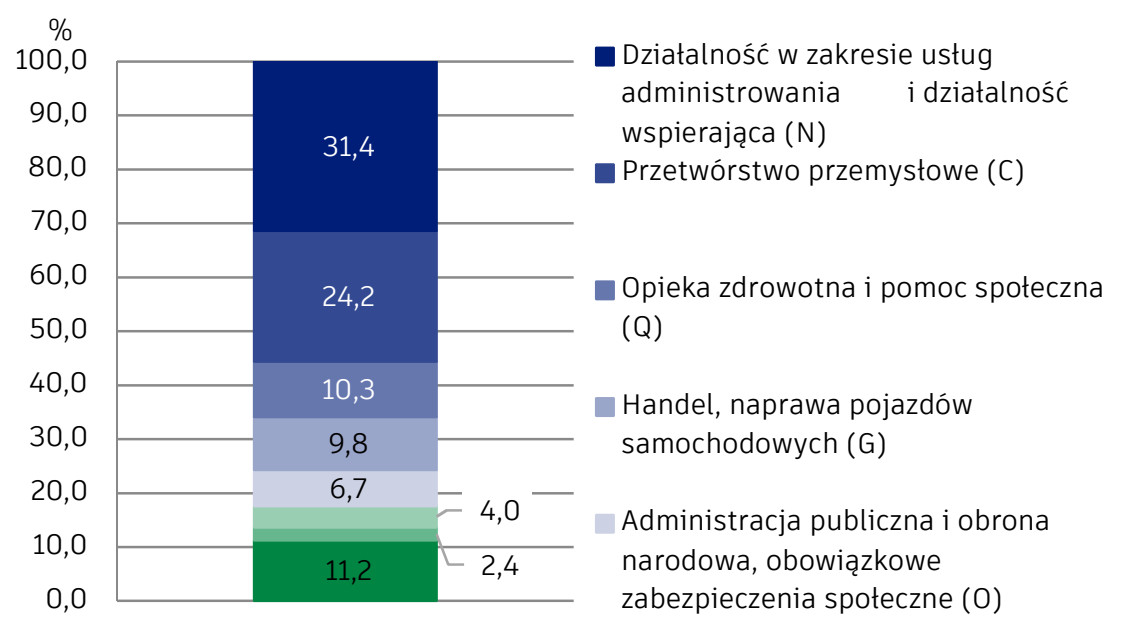

Rysunek 2. Struktura pracujących osób niepetnosprawnych w 2019r [14]

Zgodnie z danymi udostępnionymi przez GUS w grudniu 2019r. w podmiotach zatrudniających 10 osób i więcej pracowało 344,3 tys. osób niepełnosprawnych. Działalnościami, w których były zatrudnione osoby niepełnosprawne w 2019 roku są [14]:

- usług administrowania i działalności wspierającej $(31,4 \%)$ :

$>$ działalność detektywistyczna i ochroniarska $(19,9 \%)$,

$>$ działalność usługowa związana $\mathrm{z}$ utrzymaniem porządku w budynkach i zagospodarowaniem terenów zieleni $(8,7 \%)$,

- przetwórstwo przemysłowe $(24,2 \%)$,

- opieka zdrowotna $(10,3 \%)$. 
Natomiast za rok 2020 nie podano jeszcze szczegółowych statystyk dotyczących procentowego udziału osób niepełnosprawnych w poszczególnych sektorach, wiadomo jednakże, że ogólna liczba zatrudnionych niepełnosprawnych wynosiła 444 tysiące [9].

\subsection{Dostosowania i udogodnienia dla niepełnosprawnych w przedsiębiorstwach produkcyjnych}

Pracodawca, który zatrudnia osoby niepełnosprawne ma obowiązek dostosować stanowisko pracy oraz dojścia do niego- do potrzeb i możliwości tego pracownika zwracając szczególną uwagę na ograniczenia pracownika [5]. Wytyczne związane z dostosowaniem miejsca pracy dla osoby z niepełnosprawnością różnią się od siebie w zależności od stopnia i rodzaju niepełnosprawności[5-17]. Przystosowanie stanowiska pracy z maszyną lub innym urządzeniem technicznym, przy którym pracuje osoba niepełnosprawna ruchowo jest zależne od stopnia oraz rodzaju niepełnosprawności tego pracownika. Jeśli jest to osoba poruszająca się na wózku inwalidzkim powinna mieć ona zapewnioną odpowiednią ilość miejsca pozwalającą na swobodne poruszanie się na stanowisku. Oczywiście zakres obowiązków takiego pracownika również powinien być dostosowany do jego możliwości. Osoby z niepełnosprawnością ruchową mogą pracować w różnych obszarach m.in. przy taśmie produkcyjnej, przy montażu elementów, a nawet mogą zajmować się obsługą maszyn o ile stopień i rodzaj niepełnosprawności na to pozwala. Natomiast jeśli na danym stanowisku pracuje osoba na wózku inwalidzkim wtedy należy[3]:

- wszystkie potrzebne instrukcje, narzędzia, materiały a także półki, stoliki itp. umieścić $\mathrm{w}$ maksymalnym zasięgu pracownika co pozwoli mu swobodnie sięgać po potrzebne materiały (maksymalnie $1,4 \mathrm{~m}$ od podłoża),

- zachować odległości zapewniające swobodne przemieszczanie się na wózku między maszynami, urządzeniami

- zapewnić wolną przestrzeń bezpośrednio przy obsługiwanej maszynie lub urządzeniu technicznym nie mniejszą niż $0,9 \mathrm{~m}$ x $1,2 \mathrm{~m}$ co pozwoli swobodne podjechanie do maszyny i jej obsługę,

- ustawić wysokość powierzchni lub strefy roboczej w maszynie lub urządzeniu technologicznym tak by pracownik mógł swobodnie pracować. Wysokość ta powinna być indywidualnie dostosowana do wymiarów antropometrycznych pracownika.

- wszystkie dźwignie, przyciski czy inne elementy sterownicze za pomocą których pracownik przesuwa, podnosi materiał, przedmiot lub wykonuje operacje w maszynie umieścić w maksymalnym zasięgu rąk pracownika (na wysokości od $0,4 \mathrm{~m}$ do $1,4 \mathrm{~m}$,

- umieścić panel sterowniczy lub jego elementy, które są wmontowane w konstrukcję maszyny lub urządzenia tak by były one dostępne i umieszczone zgodnie z wytycznymi w tabeli. 
Tabela 1. Gtębokość i wysokość położenia elementów sterowniczych $w$ maszynie technologicznej lub innym urzadzeniu technicznym [3]

\begin{tabular}{|c|c|}
\hline Głębokość $[\mathrm{m}]$ & Wysokość $[\mathrm{m}]$ \\
\hline$<0,3$ & $1,35 \div 1,40$ \\
\hline $0,3 \div 0,38$ & 1,30 \\
\hline $0,38 \div 0,48$ & 1,25 \\
\hline $0,48 \div 0,56$ & 1,20 \\
\hline $0,56 \div 0,60$ & $<1,20$ \\
\hline
\end{tabular}

Kolejnym przykładem dostosowania dla osób z niepełnosprawnością ruchową należy sprawdzić ograniczenie olśnienia bezpośredniego od opraw oświetlenia ogólnego na stanowisku pracy. Wynika to $\mathrm{z}$ tego, że osoba $\mathrm{z}$ niepełnosprawnością jest $\mathrm{w}$ innej pozycji niż pozostali pracownicy w tym samym pomieszczeniu i wykonujący tą samą pracę, na przykład w danym pomieszczeniu wszyscy pracownicy wykonują swoje zadania $\mathrm{w}$ pozycji stojącej, natomiast osoba $\mathrm{z}$ niepełnosprawnością ruchową wykonuje to samo zadanie siedząc na wózku inwalidzkim (ma inne położenie oczu względem opraw). W takiej sytuacji należy sprawdzić czy wyżej wspomniane zjawisko olśnienia jest wystarczająco ograniczone. Dodatkowym udogodnieniem w tej kwestii jest też umieszczenie włącznika w odpowiednim miejscu w przypadku gdy np. osoba jest na wózku, włącznik powinien być w zasięgu ręki lub gdy osoba ma niepełnosprawność kończyn górnych wtedy włącznik może być umiejscowiony na podłodze[4]. Kolejnym udogodnieniem jest czujnik ruchu lub czujnik reagujący na głos, który uruchamia oświetlenie w pomieszczeniach i na korytarzach, z których korzysta osoba niepełnosprawna[4].Pracodawca zatrudniający osoby z niepełnosprawnością ruchową powinien zlokalizować ich stanowiska pracy, stołówkę, toalety oraz wszystkie inne pomieszczenia, z których te osoby korzystają na jednym poziomie by łatwo i szybko mogły się przemieszczać. Jest to również ułatwienie w przypadku gdyby konieczna była ewakuacja zakładu[5]. Dodatkowymi udogodnieniami dla osoby $\mathrm{z}$ niepełnosprawnością układu ruchu są znaki ewakuacyjne, które pomagają szybko, sprawnie i bezpiecznie opuścić budynek. Oprócz standardowych znaków ewakuacyjnych i informacyjnych w przedsiębiorstwie zatrudniającym osoby z niepełnosprawnością ruchową powinny być zamontowane znaki specjalnie przeznaczone dla tych osób i są to m.in.[5-7]:

- $\quad$ znaki ewakuacyjne[5-7]:

a)

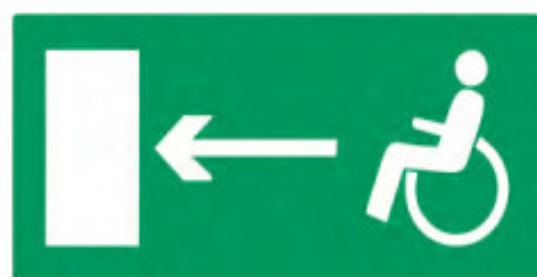

b)

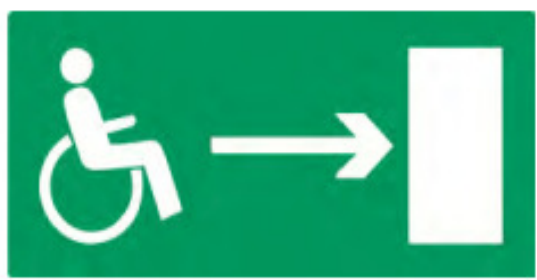

Rysunek 3. Znak wskazujacy drzwi ewakuacyjne dla niepetnosprawnych, otwieranych: a) w prawo, b) w lewo [5-7] 
a)

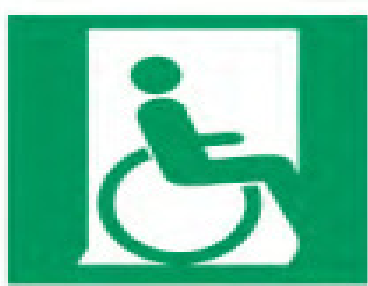

b)

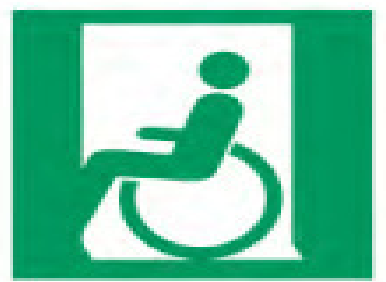

Rysunek 4. Znaki wskazujące kierunek wyjścia drogi ewakuacyjnej dla osób niepetnosprawnych a) $w$ prawo, $b$ ) w lewo [5-7]

a)
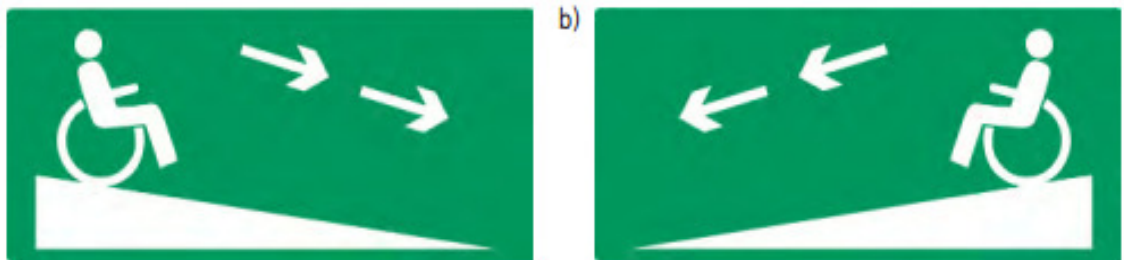

Rysunek 5. Znaki wskazujące zjazd ewakuacyjny na niższa kondygnację dla osób niepetnosprawnych a) $w$ prawo, b) $w$ lewo [5-7]

- znaki informacyjne [8]

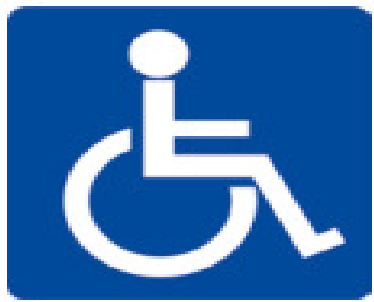

Rysunek 6. Znak informacyjny oznaczajacy petna dostępność dla wszystkich osób niepetnosprawnych [8]
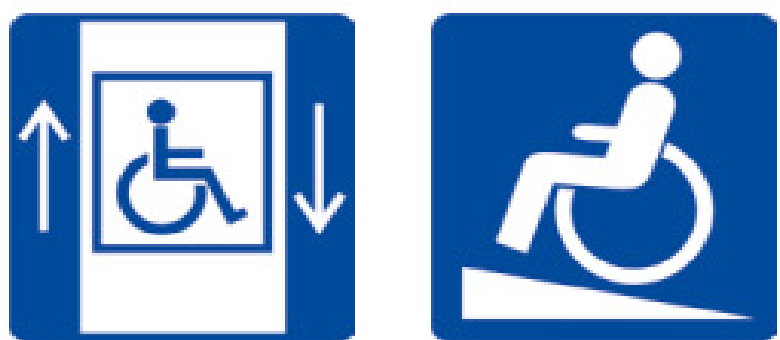

Rysunek 7. Przykładowe znaki informacyjne o dostepności dla osób poruszajacych się na wózkach inwalidzkich i z trudnościami w poruszaniu się [4] 


\section{Podsumowanie}

Analizując statystyki dotyczące zatrudniania osób z niepełnosprawnościami można stwierdzić, że liczba osób aktywnych zawodowo na przestrzeni wielu lat wzrasta, jednak nie jest to sytuacja gdzie można stwierdzić, że osoby z niepełnosprawnościami są w pełni aktywne zawodowo.

Utrzymywanie polityki informacyjnej co do zatrudniania osób niepełnosprawnych powinno być o wiele szersze, budowanie coraz większej świadomości w społeczeństwie ułatwi zatrudnianie tych osób.

Aktywizacja zawodowa osób niepełnosprawnych jest niezwykle ważna, ponieważ umożliwia to rozwój osób borykających się z upośledzeniami oraz daje szansę na ich normalne funkcjonowanie w społeczeństwie.

Osoby niepełnosprawne są wbrew ogólnie panującym stereotypom równie wartościowymi pracownikami, mogą zdobywać te same kwalifikacje i wiedzę co osoby pełnosprawne.

Dostosowanie przestrzeni pracy do osób niepełnosprawnych nie powinno ograniczać się do przystosowania wyłącznie stanowiska pracy.

Zatrudniający osoby z niepełnosprawnością powinien zaplanować przestrzeń pracy, począwszy od infrastruktury zewnętrznej zakładu pracy i umożliwić, dojście do zakładu pracy.

Pracodawca powinien mieć wiedzę na temat rodzaju niepełnosprawności osób zatrudnionych na konkretnych stanowiskach.

Pracodawca zatrudniający osoby niepełnosprawne może zyskać z tego tytułu wiele korzyści.

\section{LITERATURA}

1 FEDEROWICZ M.: Droga przez instytucje, Instytucje działające na rzecz osób niepełnosprawnych $1994 \mathrm{r}$.

2 HAINES H.: Eingliederung Behinderter, tł..Brzezińska B „Adaptacja osób niepełnosprawnych” wydawnictwo „Wokół Nas”, 1991r.

3 KALWASIŃSKI D.: Bezpieczeństwo użytkowania maszyn i innych urządzeń technicznych- Ramowe Wytyczne, Centralny Instytut Ochrony Pracy Państwowy Instytut Badawczy, Warszawa 2014r.

4 PAWLAK A., WOLSKA A.: Oświetlenie i sygnalizacja wizualna - Ramowe Wytyczne, Centralny Instytut Ochrony Pracy - Państwowy Instytut Badawczy, Warszawa, 2014.

5 WALICHNOWSKI A, PRZYBYSZEWSKA A, GAJWESKA K, Architektoniczne projektowanie obiektów i pomieszczeń pracy - Ramowe Wytyczne, Centralny Instytut Ochrony Pracy - Państwowy Instytut Badawczy, Warszawa 2014r.

6 Ustawa z dnia 27 sierpnia 1997 r. o rehabilitacji zawodowej i społecznej oraz zatrudnianiu osób niepełnosprawnych (tekst jedn.: Dz. U. 2021, Poz. 573)

7 PN-N-01256-02:1992 Znaki bezpieczeństwa. Ewakuacja.

8 PN-Z-80101:2007 Dostępność obiektów i urządzeń dla osób niepełnosprawnych. Znaki informacji publicznej 
9 Serwis internetowy Biura Pełnomocnika Rządu do Spraw Osób Niepełnosprawnych- Dane na podstawie BAEL:

http://www.niepelnosprawni.gov.pl/p,81,bael , 15.10.2021r.

10 Serwis internetowy Biura Pełnomocnika Rządu do Spraw Osób Niepełnosprawnych - Racjonalne usprawnienia: http://www.niepelnosprawni.gov.pl/a,6,racjonalne-usprawnienia-pjm, 07.10.2021r.

11 Serwis internetowy Encyklopedii PWN - Definicja niepełnosprawności https://encyklopedia.pwn.pl/haslo/niepelnosprawnosc;3947453.html, 29.09.2021r.

12 Serwis internetowy Fundacji Adams- Korzyści z zatrudnienia osób niepełnosprawnych:https://fundacjaadams.org.pl/zatrudnienie-osobyniepelnosprawnej-korzysci/ dostęp z dnia 31.10.2021r .

13 Serwis internetowy Głównego Urzędu Statystycznego- Osoby niepełnosprawne w 2018 roku: https://stat.gov.pl/obszary-tematyczne/warunki-zycia/ubostwopomoc-spolecznalosoby-niepelnosprawne-w-2018-roku,24,1.html ,15.10.2021r.

14 Serwis internetowy Głównego Urzędu Statystycznego- Osoby niepełnosprawne w 2019 roku: https://stat.gov.pl/obszary-tematyczne/rynek-pracy/pracujacybezrobotni-bierni-zawodowo-wg-bael/osoby-niepelnosprawne-w-2019roku,33,1.html , 14.10.2021r.

15 Serwis internetowy Kadr Infor- Korzyści z zatrudniania niepełnosprawnych https://kadry.infor.pl/kadry/inne_formy_zatrudnienia/mlodociani_niepelnospra wni_bezrobotni/676909,Korzysci-z-zatrudniania-niepelnosprawnych.html dostęp z dnia 31.10.2021r

16 Serwis internetowy PFRON- Ustawa o rehabilitacji zawodowej i społecznej oraz zatrudnianiu osób niepełnosprawnych: https://www.pfron.org.pl/fileadmin/ftp/dokumenty/SODiR/Akty_prawne/ustawa _o_reh_2013_.pdf, 02.10.2021r.

17 Serwis internetowy Państwowej Inspekcji Pracy- Niepełnosprawny pracownik: https://www.pip.gov.pl/pl/f/v/121848/niepelnospr\%20pracow.pdf, 16.10.2021r.

18 Serwis internetowy Pkt.pl- O zatrudnieniu osób niepełnosprawnych w firmach produkcyjnych:

https://www.pkt.pl/artykul/o-zatrudnieniu-osob-niepelnosprawnych-w-firmachprodukcyjnych-16656,04.10.2021r

19 Serwis internetowy praca.pl- Zakład Pracy Chronionej: https://www.praca.pl/poradniki/rynek-pracy/zaklad-pracy-chronionej-czymjest,warunki,przepisy,dofinansowanie_pr-1977.html, 12.10.2021r 